\title{
THE INVENTION OF TRADITIONAL KNOWLEDGE
}

\author{
MADHAVI SUNDER*
}

\section{I \\ INTRODUCTION}

In late December 2004 I traveled to India to witness the social ruptures that India's entry into the modern intellecual property world would likely trigger. The deadline for developing nations to be fully compliant with the Agreement on Trade-Related Aspects of Intellectual Property (TRIPs), the preeminent global intellecual property law of the Information Age, was January 1, 2005. From that date on, India would have Western-style intellecual property rights in everything from medicines to seeds. For more than a decade, the developing world had resisted this moment. Since they had been pressured into signing TRIPs during the Uruguay Round of WTO negotiations, countries such as Brazil and India had argued that strong intellecual property rights helped the West but would devastate the rest.

Sadly, my visit to India that December bore witness to an all too literal tsunami that shook the Subcontinent. The tsunami focused the world's attention on the rural poor in the countries at the perimeter of the Indian Ocean. I will seek to keep my focus on these people in this article.

Much to my surprise, India rang in the New Year without much ill note of TRIPs. In the intellecual property storm, the dust had settled, for now. TRIPs was finally in India, seemingly to stay, and the intellecual property scholars and practitioners there with whom I spoke had little interest in prolonging the

Copyright $($ C 2007 by Madhavi Sunder. Anyone may make copies of this article for noncommercial purposes so long as the following notice is retained on all publicly distributed copies:

(C) 2007 Madhavi Sunder. Originally published in Symposium, Cultural Environmentalism @

10, 70 LAw \& CONTEMP. Probs. (James Boyle \& Lawrence Lessig, eds., Spring 2007).

Licensed under the Creative Commons Attribution-NonCommercial License. To view a copy

of this license, visit http://creativecommons.org/licenses/by-nc/3.0/ or send a letter to Creative

Commons, 543 Howard Street, 5th Floor, San Francisco, California, 94105, USA.

This article is also available at http://www.law.duke.edu/journals/lcp.

* Carnegie Corporation Scholar 2006-08; Professor of Law, University of California, Davis. J.D., Stanford Law School, 1997; A.B., Harvard College, 1992. This article gained tremendously from the foundational work and intellectual leadership of James Boyle and Larry Lessig, as well as the entire community of twenty-first century American intellecual property scholars, an astounding number of whom were in attendance at the "Cultural Environmentalism at 10" conference at Stanford Law School in March 2006. Particularly illuminating were my exchanges with Yochai Benkler, James Boyle, Anupam Chander, Maggie Chon, Terry Fisher, Mark Lemley, Arti Rai, and Molly Van Houweling. Thanks also to Rochelle Dreyfuss and Jane Ginsburg, and to their intellectual property students, for insightful comments. Sheirin Ghoddoucy provided excellent research assistance. 
battles of the last decade. "TRIPs has entered, and India took a U-turn because it felt it could not [continue fighting against TRIPs]," V.C. Vivekanandan, an intellecual property professor at NALSAR, a leading national law school in Hyderabad, told me. "It has been grudgingly accepted."

But in that characteristically Indian way of absorbing every contradiction and all the diversity of life, this was not simply an expression of passive acceptance of destiny. After a decade of resisting the Western imposition of intellectual property, now many in India-from the intellecual property professors and lawyers in the cities to the farmers and artisans in the villageswere beginning to ask: how can intellecual property rights work for them? TRIPs protected the knowledge and economic interests of the developed world, the rich corporations of the West. Can intellectual property be a tool for protecting poor people's knowledge as well? Many seem to think so. Take the case of an award-winning farmer in Kerala who developed a high-yield method for planting rubber trees. An intellecual property professor from Kerala related the farmer's story: "Later when somebody tried to plant [rubber trees] in the same way, [the farmer] said, 'No, I will get a patent in this." The professor noted, "Five years back this concept [of patenting] was totally lacking. This farmer had only studied up to [the] sixth or seventh [grade]. But he has some idea about this particular law where you can stop somebody else from using the method."

Certainly, the shift to appropriating intellectual property in India is neither complete nor uncontested. When the Kerala farmer took his claims to the Rubber Board, there was fierce debate among the farmers. "One young farmer stood up and said, 'I [wouldn't] want any monetary benefit from this. I [would] just want this to be propagated freely. Uncle, I [wouldn't] want a patent. For me the honor of the award [would be] enough."' 3 But if the daily headlines are any indication, the country's approach is shifting from this traditional view. The front pages chronicle a rising tide of applications filed with a national registry established pursuant to the Geographical Indication of Goods (Registration and Protection) Act of 1999 (GI Act). ${ }^{4}$ Required by TRIPs ${ }^{5}$ originally as a means to protect French makers of wines and champagnes, the law gives trademark-like protection to distinctive goods or services whose quality and reputation derive from the geographical area in which they are produced. In a country such as India, which has a vast cultural heritage and a store of traditional knowledge dating back to the Vedas, the GI Act is seen as a potentially important source

1. Interview with V.C. Vivekanandan, Professor, Nalsar Univ. of Law, in Hyderabad, India (Dec. $28,2004)$.

2. Interview with V.K. Unni, Professor, Nalsar Univ. of Law, in Hyderabad, India (Dec. 30, 2004).

3. Id.

4. No. 48, Acts of Parliament, 1999 [hereinafter GI Act]. The GI Act became effective in 2003. Id.

5. Agreement on Trade-Related Aspects of Intellectual Property Rights, Apr. 15, 1994, Marrakesh Agreement Establishing the World Trade Organization, Annex 1C, Legal InstrumentsResults of the Uruguay Round, Arts. 22-24, 1869 U.N.T.S. 299, 33 I.L.M. 1197 (2004) [hereinafter TRIPs]. 
of recognition and income for India's rural poor-the very same poor who otherwise have been displaced and forced further into poverty by globalization. One hope is that Geographical Indication (GI) protection will allow local artisans to stay in their communities and fend for themselves, without having to renounce their traditional work for life in the overcrowded cities. When I visited India in 2005, farmers and artisans from across the country were getting in line to register their wares, from Darjeeling tea to Alfonso mangoes, Kolhapuri cheppals, Mysore silk and sandalwood, and the uniquely woven sarees from the village of Pochampally in the shadow of high-tech Hyderabad. ${ }^{6}$ The list of applicants for Indian GI status is growing. On my visit this past December, Madhubani paintings, which hang in my home in California, had been added to the queue.

Turn the clock back ten years. When intellectual property had found its way into the sanctions regime of the international trade order, there were no marchers in the streets to mark the occasion. The White House issued a white paper declaring the need to strengthen intellecual property law in the face of the digital revolution. Congress was just about to undertake enormous giveaways to intellecual property holders-granting famous brands rights even in the absence of consumer confusion, extending copyright terms by another two decades, and securing technological copyright protection schemes against hacking. Courts signaled their willingness to accept patents on business methods. In the new economy of the information age, patents, trademarks, copyrights, and even domain names ${ }^{7}$ were being distributed with abandon. Conventional wisdom was that the digital world to come would require bigger and stronger intellecual property rights.

Amid this euphoria, James Boyle recognized a dark side of intellectual property. In this narrative of progress, Boyle saw us sowing the seeds of our own destruction. Just as the first enclosure of the commons and industrialization had threatened our natural environment, this new "land grab" in cyberspace and on our cultural commons, Boyle observed, threatened to ruin our cultural landscape and deplete our cultural heritage. Boyle's critical insight was that expanding intellecual property rights were fed by the conceit of romantic authorship: the idea that individuals (and even corporations) create out of thin air rather than borrow from a rich public domain of freely circulating sources and inspirations. "The author vision blinds us to the importance of the commons-to the importance of the raw material from which information products are constructed," he wrote in his 1996 book, Shamans, Software, and Spleens: Law and the Construction of the Information Society. ${ }^{8}$ The process of

6. See Pochampally Paves the Way for Local IP Protection, ECON. TIMES, Dec. 19, 2004.

7. See Anupam Chander, The New, New Property, 81 TEX. L. REV. 715 (2003) (discussing the allocation of property rights in Internet domain names).

8. JAMEs Boyle, SHAmans, SOFTwARE, AND SPleENS: LAW AND THE CONSTRUCTION OF THE INFORMATION SOCIETY Xiv (1996). 
creation, Boyle noted, requires the conservation of cultural raw materials; if these are themselves owned, the process of creation may be stunted.

The rest is history. The book went on to become an intellecual property classic for our generation. Boyle's vision of a political movement to protect and preserve the public domain, complete with private institutions dedicated to the project modeled after Greenpeace, spurred the establishment of the Creative Commons. On a personal level, reading the book in law school influenced my decision to become a law professor.

Less noted but equally profound, the metaphor Boyle offered, "cultural environmentalism," helped lay the foundation for the recognition and protection of traditional knowledge and natural resources found in the developing world. Taking a cue implicitly from the environmental justice movement, which demonstrated the disparate effects of environmental harms on disadvantaged minorities, the cultural-environmental movement illustrated how third-world peoples are disproportionately disadvantaged by intellecual property law, which historically has not recognized their cultural contributions. Indigenous people and those in the third world benefited from the attention to our cultural commons. It provided a moral and economic basis to reward their cultivation of the world's biodiversity and ancient cultural knowledge about that biodiversity, both of which were required inputs for innovation. By "reifying the negative" and focusing needed attention on the "other side" of intellectual property ${ }^{10}$ Boyle invented the public domain.

But Boyle's depiction suggests there are only two sides to the story. In fact, there are many views of the cathedral. Now, in the developing world, scholars, lawyers, and activists are turning the light on "poor people's knowledge." ${ }^{11}$ For them, this is "the other half of intellectual property"-the knowledge that is not protected by TRIPs, but perhaps should be. ${ }^{12}$ In this article, I consider how "cultural environmentalism" both bolsters and obstructs the project of protecting poor people's knowledge and promoting development through intellectual property. I argue that although the metaphor spurred the invention of traditional knowledge as a political and legal category, the same metaphor may also obscure the inventiveness of traditional knowledge. Reifying the public domain may have the unintended effect of congealing traditional knowledge as "the opposite of property," ${ }^{13}$ presenting poor people's knowledge as the raw material of innovation - ancient, static, and natural-rather than as intellectual property-modern, dynamic, scientific, and cultural invention. Under this view, traditional knowledge holders may receive remuneration for conserving

9. James Boyle, The Second Enclosure Movement and the Construction of the Public Domain, 66 LAW \& CONTEMP. PROBS. 33, 69 (Winter/Spring 2003).

10. See generally James Boyle, Foreword: The Opposite of Property?, 66 LAW \& CONTEMP. PROBS. 1 (Winter/Spring 2003).

11. See generally Poor People's Knowledge: Promoting Intellectual Property in Developing Countries (J. Michael Finger \& Philip Schuler eds., 2004).

12. Id. at back cover.

13. Boyle, supra note 10 , at 1 . 
biodiversity and contributing the raw materials of innovation, but they are not recognized as intellecual property holders in their own right. What's more, a binary view of "intellectual property versus the public domain" rejects new claims for intellectual property in traditional knowledge on the premise that these rights would shrink the public domain. ${ }^{14}$

In truth, the line between what law considers "raw material" versus "intellectual property" is less stable and more fraught with bias than the binary approach would acknowledge. While politically effective, reifying the negative may have the perverse effect of reinventing these categories as real and stable, obscuring the degree to which they are constructed and insecure.

If anyone understands this, it is Boyle himself. He is, after all, the author of "Foucault in Cyberspace." 15 One of his fundamental concerns in Shamans, Software, and Spleens was with the contested concept of authorship. Why was the shaman's lore unprotected "traditional knowledge" but W.R. Grace's appropriation of that knowledge "innovation"? Why was Mr. Moore's spleen "raw material" but the UCLA researchers' cell line derived from the spleen "intellectual property"? These were more than the sharp questions of a law professor challenging first-year property students. Boyle offered up the "romantic author" not to justify these categories but to deconstruct them. Boyle persuasively argued the need to critically probe authorship and its premise of "transformative originality more often assumed than proved." "16

How is it, then, that Boyle's work may now be inadvertently helping to reconstruct some of the very same false binaries he set out to tear down more than a decade ago? The answer, I believe, turns on the historical contingency the work, its intellectual history. In Shamans, Software, and Spleens, Boyle was concerned about the morality of legally recognizing some members of society as authors and not others. He bemoaned the distributive effects of such intellecual property laws as "colossally unfair" ${ }^{17}$ and boldly called for "a critical social theory of the information society" by and large, Boyle's own work did not stray far from intellectual property's economic tradition. While Boyle acknowledged the broad social, cultural, moral, and distributive effects of intellectual property, his primary prescriptions stuck to a law-and-economic analysis of intellectual property. Failure to protect a public domain was, above all, inefficient. Destroying the raw materials necessary for creation would stunt creation itself. This approach was admittedly strategic; Boyle openly stated that economic appeals "will sometimes convince

14. See, e.g., Kal Raustiala, Density \& Conflict in International Intellectual Property Law, 40 U.C. DAVIS L. REV. 1021, 1036 (2007) (commenting that protections for geographical indications in the global South "may exacerbate an already troubling erosion of the public domain.").

15. James Boyle, Foucault in Cyberspace: Surveillance, Sovereignty, and Hard-Wired Censors, 66 U. CIN. L. REV. 177 (1997).

16. BOYLE, supra note 8 , at xii.

17. Id. at 142 ("If one has the slightest concern for distributional justice in one's criteria for property regimes, this regime must surely fail.").

18. Id. at xiv. 
when more frankly moral appeals do not." ${ }^{, 19}$ For all its paradigm shifting, in the end Boyle acknowledged that his approach was not radical, but rather that it evinced "a conservative strand," advocating "a return to the rational roots of intellectual property." ${ }^{20}$

Boyle displayed a rare combination: postmodern acuity and political savvy. His analogy to the environmental movement was a brilliant move. But given the discursive restraints of the time, Boyle was not able to fulfill his ambition completely. He openly acknowledged "the dangers of embracing too closely a language that can express only some of the things that you care about." ${ }^{21} \mathrm{~A}$ decade ago, Boyle was fully aware of the contingency of his own position, recognizing that "our concerns with education and the distribution of wealth, with free speech and universal access to information, can never be fully expressed in the language of neo-classical price theory." ${ }^{22}$

Today, thanks in large part to Boyle himself and to the prescient work of other intellecual property scholars, from Pamela Samuelson ${ }^{23}$ to Vandana Shiva $^{24}$ to Lawrence Lessig, ${ }^{25}$ the space for discussing intellectual property's distributive and social effects is expanding. Notably, a vast coalition of hundreds of intellecual property practitioners, scholars, and activists from around the world are calling for intellectual property to be approached in the context of broader societal interests and development-related concerns, and not just from the narrow lens of economic incentives for innovation. ${ }^{26}$ This symposium,

19. James Boyle, A Politics of Intellectual Property: Environmentalism for the Net?, 47 DUKE L.J. 87, 114 (1997). In SHAMANS, SOFTWARE, AND SPLEENS, Boyle wrote:

Whether I am right or wrong about the distributional effects, I think it can be convincingly demonstrated that an exclusively author-centered regime will have negative effects on efficiency. In many ways, this may be the more important point to make. To condemn a system as unfair is one thing; to argue that it does not work, that it may sometimes actually impede innovation, is another.

Supra note 8, at 127 (emphasis in original).

20. James Boyle, A Manifesto on WIPO and the Future of Intellectual Property, 2004 DUKE L. \& TECH. REV. 0009, 11, http://www.law.duke.edu/journals/dltr/articles/PDF/2004DLTR0009.pdf.

21. BOYLE, supra note 8 , at 114.

22. Id. at 115 .

23. See Pamela Samuelson, The Copyright Grab, WIRED, Jan. 1996, available at http://www.wired.com/wired/archive/4.01/white.paper_pr.html (criticizing the policy of the Clinton administration regarding intellectual property).

24. See generally VAndana Shiva, Biopiracy: THE Plunder of NATURE AND KNOWLEdge (1997).

25. See LAWrenCe LeSSIG, FreE CUltURE xiv (2004) (arguing that a combination of technology policy and copyright has transformed our "free culture" into a "permission culture" in which creators get to create only with the permission "of the powerful").

26. See World Intellectual Property Organization, Geneva Declaration on the Future of the World Intellectual Property Organization (Oct. 4, 2004), available at http://www.cptech.org/ip/wipo/ futureofwipodeclaration.html (writing that the expansion of intellecual property law's mandate should be from an exclusive focus on "efficient protection" and "harmonization" to "fairness, development and innovation."). The WIPO General Assembly responded to the call, voting that same month to incorporate a "development agenda" into its intellecual property law and policy. World Intellectual Property Organization, Proposal by Argentina and Brazil for the Establishment of a Development Agenda for WIPO, WO/GA/31/11, (Aug. 27, 2004), available at http://www.wipo.int/documents/en/ document/govbody/wo_gb_ga/pdf/wo_ga_31_11.pdf. The proposal was joined by a group of ten other 
"Cultural Environmentalism @ 10," is an opportunity for us to revisit Boyle's work, to consider its continuing relevance in this new time and place. As ever, we are enriched by tradition, but not beholden to it. We are still in need of "a critical social theory of the information society" for which Boyle's work offers a foundation. But since then, the discursive space for crafting that theory has expanded beyond the narrow confines of understanding intellecual property rights as incentives alone.

In this article, I pay homage to Boyle's innovation in my own way. Part II argues that by foregrounding the important role of "raw materials" in the process of innovation, cultural environmentalism helped provide a theoretical and political basis for recognition and recompense for the purveyors of those raw materials-often indigenous peoples who have cultivated the earth's biodiversity and who hold "traditional knowledge" about that biodiversity. The invention of the public domain helped to foster "the invention of traditional knowledge" as a political and legal category worthy of rights. But while Boyle's theory of the public domain provided intellectual heft to new claims for traditional knowledge protection, so, too, has it proved a stumbling block. Today, the 1992 Convention on Biological Diversity (CBD)—and, more recently, the draft of a proposed Access to Knowledge Treaty (A2K)—promote an international legal regime that would reward traditional knowledge holders for their role in preserving biodiversity and ancient knowledge-that is, for their role in preserving the public domain. But these international legal documents do not expressly recognize the inventiveness of traditional knowledge, or the attendant intellecual property rights claimed by the world's poor as authors and inventors of new knowledge. Part III argues that traditional knowledge is much more dynamic and innovative-indeed evolving - than the "environmentalism" metaphor, with its connotations of conservation, acknowledges.

I explore the theoretical implications of this shift in understanding poor people's knowledge in Part IV. I argue that a legal regime that recognizes poor people as agents - that is, as the subjects of intellectual property, and not just as the objects of intellectual property, offering up raw materials for others to transform-is premised upon a broader view of the relationship between intellectual property and development itself. Here, yet another side of intellectual property is revealed: its social and cultural face, not just the economic. World actors are beginning to recognize that intellectual property is about more than incentives for innovation. Just like real property rights, intellecual property rights can promote freedom and security, potentially

countries, which called themselves the "Friends for Development." World Intellectual Property Organization, Proposal to Establish a Development Agenda for WIPO: An Elaboration of Issues Raised in Document WO/GA/31/11, IIM/1/4, (Apr. 11-13, 2005), available at http://www.wipo.int/ edocs/mdocs/mdocs/en/iim_1/iim_1_4.pdf [hereinafter Elaboration of Issues]. The countries were Bolivia, Cuba, the Dominican Republic, Ecuador, Iran, Kenya, Sierra Leone, South Africa, Tanzania, and Venezuela. $I d$. 
enabling knowledge societies in which the rich and poor alike may cultivate and materially benefit from their ideas.

\section{II}

\section{WARDENS OF KNOWLEDGE}

The invention of the public domain helped lay a foundation for "the invention of traditional knowledge" as a political and legal category worthy of rights. Boyle's metaphor for a politics of the public domain, "cultural environmentalism," helped focus the world's attention on the value of ecological and cultural biodiversity for the process of scientific and cultural innovation, and of the need to preserve those resources. Although Boyle offered cultural environmentalism as a metaphor, at points cultural environmentalism coincides with environmentalism itself. Recall the shamans of Madagascar. In this poverty-stricken nation, medicine men had developed therapeutic uses for the indigenously grown rosy periwinkle. Enter Eli Lilly \& Company, which transformed this plant and the shaman's lore into a drug to treat Hodgkin's disease. At the time, the drug was valued at some \$100 million annually. ${ }^{27}$ As Boyle pointed out, even a fraction of the company's profits would have been a significant boost to the economy of this poor country. ${ }^{28}$ But through the vagaries of Western intellecual property law, the people of Madagascar received nothing of the profits derived from this new drug. Western intellectual property, as Boyle explained, was premised upon an authorial regime that "values the raw materials for the production of intellectual property at zero," yet judges Eli Lilly's contribution, refining the shaman's traditional knowledge, in the hundreds of millions. ${ }^{29}$

For Boyle, the rosy periwinkle symbolized more than just a moral problem, or a problem of postmodern authorship. The rosy periwinkle, Boyle wrote, "exemplifies the utilitarian failures of the current regime." ${ }^{30}$ Absent any reward for their preservation of biodiversity and traditional knowledge, the people of Madagascar had "chopped down most of their forests to feed [their] people" an irony Boyle decried. In this context, the cultural environment was not merely metaphor. Boyle was concerned about the literal environment, the earth's forests and all of its abundant biodiversity, from which medicinal and other cultural knowledge could be derived. Cultural environmentalism called our attention to the traditional knowledge of the shaman and other people, often poor, who cultivated disease-resistant wheat and rice and held the secrets of which plants could cure our ills. Going further, cultural environmentalism

27. BOYLE, supra note 8 , at 128 . For other helpful analyses of the rosy periwinkle controversy see Shayana Kadidal, Plants, Poverty, and Pharmaceutical Patents, 103 YALE L.J. 223, 223 (1993); Srividhya Ragavan, Protection of Traditional Knowledge, 2 MinN. InTELl. Prop. ReV. 1, 8 (2001).

28. BOYLE, supra note 8, at 128.

29. Id. at 126 (emphasis omitted).

30. Id. at 142 (emphasis added).

31. Id. at 128 . 
highlighted the need to preserve diverse cultures, the repositories of such knowledge. "Who knows what other unique and potentially valuable plants disappear with the forest, what generations of pharmacological experience disappear as the indigenous culture is destroyed?" Boyle pointedly asked. ${ }^{32}$

The trope of the romantic author obscured the contributions of biodiversity and traditional knowledge to innovation. "Who needs a public domain if you can create out of nothing?" Boyle asked. ${ }^{33}$ By exposing how companies such as Eli Lilly did not, in fact, create out of thin air, but rather often benefited from the rich biodiversity and knowledge found in the global South, Boyle made the strongest case for preserving the public domain: the public domain saves lives.

Boyle's theory of the public domain provided intellectual grounding to arguments for recognizing the value of the cultural contributions of indigenous and third-world peoples to innovation. Both the CBD—and, more recently, the draft of a proposed Access to Knowledge Treaty-promote an international legal regime that would reward indigenous peoples for supplying the raw materials of innovation and preserving the public domain. Employing the combined language of environmentalism and economics, the CBD refers to local peoples as "resource managers" and their trade as "species management, ${ }^{, 34}$ and grants countries sovereign rights of ownership over genetic resources found within their borders. These rights serve as both ex post reward for biodiversity conservation and ex ante incentive for continued conservation. The CBD would grant both sovereignty in biological resources and the right to share in the benefits of patented products that arise from the appropriation of a country's biodiversity or traditional knowledge. Similarly, a draft Treaty on Access to Knowledge seeks to "protect, preserve and enhance the public domain, which is essential for creativity and sustained innovation, ${ }^{35}$ by similarly requiring patent holders to seek prior informed consent for use of biological materials from the country of origin and to "equitably share the benefits derived from use of that biological material." ${ }^{36}$ The dual recommendation of both resource sovereignty and equitable benefit sharing seeks to recognize indigenous peoples as the wardens of the world's "raw materials" and to benefit them materially for their role in preserving the public domain.

Whereas this theory of the public domain has served to undergird claims for traditional knowledge protection, so too has it proved a stumbling block. In the

\section{Id. at $128-29$.}

33. Boyle, supra note 9 , at 52 .

34. Darrell A. Posey, Indigenous KNowledge AND ETHICS: A DARRell Posey ReAder 161 (Kristina Plenderleith ed., 2004); see also Conference on Environment and Development, Rio Declaration on Environment and Development, Principle 22, U.N. DoC A/CONF.151/26 (Aug. 12, 1992) ("Indigenous peoples and their communities, and other local communities, have a vital role in environmental management and development because of their knowledge and traditional practices. States should recognize and duly support their identity, culture, and interests and enable their effective participation in the achievement of sustainable development.").

35. Treaty ON ACCESS TO KNOwledge, pt. 1, Preamble (draft, May 9, 2005), available at http://www.cptech.org/a2k/consolidatedtext-may9.pdf.

36. Id. at art. 4(1)(b)(iii). 
last decade, we have seen indigenous peoples and the poor, not unlike the Kerala rubber-tree farmer, turning their attention to appropriating intellectual property to their own ends. ${ }^{37}$ Today, claims by indigenous people and the poor go beyond equitable benefit sharing; increasingly, the poor seek to own copyrights, trademarks, and patents in their own cultural and scientific innovations. ${ }^{38}$ Strikingly, the traditional advocates for preserving the public domain have flipped. "Native peoples once stood for the commons," ${ }^{, 9}$ but with the imbalance of TRIPs being more and more apparent, advocates of the poor are turning their attention to securing affirmative intellecual property rights for their own cultural and scientific innovations. Paradoxically, however, the concepts of "traditional knowledge," the "public domain," and "cultural environmentalism" are now proving to be obstacles to understanding poor people's knowledge as intellectual property. Claims by native peoples to hold intellectual property are resisted as threats to the public domain, or as the false consciousness of neo-liberalism, or as a radical assault on our intellecual property tradition, which encourages and promotes cultivation, not stewardship. ${ }^{40}$

We should be wary of these declarations and "the romance of the public domain" itself. ${ }^{41}$ Anupam Chander and I have argued that, while the banner of the public domain is taken up for all of humanity, a binary view of "intellectual property versus the public domain" may not be to the benefit of the world's poor. ${ }^{42}$ Often, we argued, the benefits of an open-access commons go to the richest and the strongest. Differences in wealth, gender, and class determine whether one will in fact be able to convert the riches of the commons into lucrative property. This is what we call the "romance of the commons: the belief that because a resource is open to all by force of law, it will indeed be equally exploited by all." ${ }^{43}$ Concerns arising from efficiency alone obscure the disparate effects of the commons on the poor. Staying attuned to the distributional effects of the public domain, in contrast, may require thinking about poor people's

37. See Michael F. Brown, Who Owns Native Culture? 55 (2003) (observing that many indigenous "lawyers and activists believe that intellectual property holds the key to heritage protection."); see generally Madhavi Sunder, Property in Personhood, in RETHINKING COMMODIFICATION 164 (Martha M. Ertman \& Joan C. Williams eds., 2005).

38. See BROWN, supra note 37, at 43-68 (chronicling efforts by Australian aboriginals to assert collective copyright in Native designs); id. at 69-94 (describing efforts to use trademark and the right of publicity to combat perceived misuse of traditional symbols, such as the image of the revered Indian leader, Crazy Horse, on malt liquor); id. at 95-143 (noting indigenous responses to ethnobotany patents).

39. Anupam Chander \& Madhavi Sunder, The Romance of the Public Domain, 92 CAL. L. REv. 1331, 1335 (2004).

40. See, e.g., Brown, supra note 37, at 8 ("The readiness of some social critics to champion new forms of silencing and surveillance in the name of cultural protection should trouble anyone committed to the free exchange of ideas.").

41. Chander \& Sunder, supra note 39 (discussing how "the romance of the public domain" works to the detriment of poor communities).

42. Id. at 1335 .

43. Id. at 1332 . 
knowledge in "uncommon property" greater control over their property and to extract compensation from their knowledge.

In this paper, I focus on the effects on the poor of the "cultural environmentalism" metaphor through its reification of the division between "raw" and "cooked" knowledge, a conceptual separation long fundamental to intellecual property law. Ironically, the cultural environmentalism metaphor has fortified the very boundary between authors and raw materials that Boyle himself had begun to tear down. Boyle pulled the rug out from under the romantic author, exposing the equally important role of sources and audiences in the process of innovation. He also underlined the vagaries and cultural bias in intellecual property law's determinations of who were authors and who (Mr. Moore) or what (his spleen) were the mere raw materials of scientific and cultural production. Boyle recognized the problem of "rewarding a narrow set of contributions to world culture and science." ${ }^{45}$ But he stopped short of advocating reform of a Western intellecual property tradition founded upon naturalizing distinctions between nature and culture, idea and expression, raw material and innovation. Anchoring his argument in the orthodox language of efficiency, Boyle praised intellectual property's tradition of striking the proper balance between intellectual property and the public domain but argued that the Information Age had upset that balance. Intellectual property could continue to promote innovation, he argued, if it returned to that balance. ${ }^{46}$

Poor people benefited from this approach to the extent their contributions toward preserving the cultural environment were unrecognized in the past. At the same time, reifying the negative has the perverse effect of congealing poor people's knowledge as the object of property, the raw material from which real intellectual property is derived, and obscures its status as the subject of property, deserving of the label intellectual property in its own right.

Reflecting on "Cultural Environmentalism at 10," we must consider how law's reification of the negative invents tradition rather than discovers it. The lines between the inputs and outputs of innovation are anything but static. At the end of the last century, we witnessed the migration of many forms of knowledge from the public domain to intellectual property: university research, business methods, and even life forms were now in the realm of intellectual property. In truth, our intellecual property traditions are more complex than political campaigns for the public domain allow us to recognize. Viewed in this light, we may begin to see how the invention of traditional knowledge as perennially raw rather than cooked erects a false wall between modernity and tradition. Worse still, it deprives diverse peoples of the world of their humanity

44. Id. at 1354 .

45. BOYLE, supra note 8, at 119.

46. See, e.g., $i d$. at xiii (bemoaning intellecual property ownership by corporations that is "so expansive that they make it much harder for future independent creators to actually create"); $i d$. at 142 (citing "the utilitarian failures of the current regime."). 
and cultural creativity. As the Indian eco-feminist and property theorist Vandana Shiva describes, biodiversity is not simply the bounty "of nature, guided by nothing but Providence." Far from it, "commons are resources shaped, managed and utilized through community control., ${ }^{, 47}$ When law defines the contributions of the poor as nature rather than culture, the "creativity of both nature and other cultures is negated." 48 Boyle underlined "law and the construction of the Information Society." ${ }^{49}$ Our understanding of information and knowledge is not preordained but involves political choices. Indeed, this is the insight of Shiva's own political act of defining as "biopiracy" the "patent claims over biodiversity and indigenous knowledge that are based on the innovations, creativity and genius of the people of the Third World." "Since a 'patent' is given for invention," she argues, "a biopiracy patent denies the innovation embodied in indigenous knowledge."

I do not claim that our ability to distinguish the inputs and outputs of innovation is entirely indeterminate. Nor do I advocate law shifting continuously according to the changing political strength of either the rich or the poor in these matters. But I do call for legal decisionmakers to recognize contingency, bias, and unreasoned orthodoxy in the legal definitions that begin to appear-every decade or so-as natural. Today, we can see how constructing poor people's knowledge as raw materials supports a model of "benefit sharing," permitting local communities to perhaps receive some compensation from Western patents derived from those communities' resources. But this approach rewards the poor only as wardens, not also as cultivators. In some cases, when the poor's innovation is overlooked, benefit sharing may be "the equivalent of stealing a loaf of bread and then sharing the crumbs., ${ }^{, 52}$

47. Vandana Shiva, Protect or Plunder? Understanding Intellectual Property RIGHTS 47 (2001). A quarter-century ago, William Cronon helped give birth to the environmental movement with a similar observation of the active role played by Native Americans in cultivating the New England environment, which colonists had deemed "natural." "One must not exaggerate the differences between English and Indian agricultures," Cronon wrote. WILLIAM CRONON, CHANGES IN THE LAND: INDiANS, COLONISTS, AND THE ECOLOGY OF NEW ENGLAND 127 (1983). As Cronon explained,

By making the arrival of the Europeans the center of our analysis, we run the risk of attributing all change to their agency, and none to the Indians. The implication is not only that the earlier world of "Indian" New England was somehow static but also that the Indians themselves were as passive and "natural" as the landscape. $I d$. at 164.

48. SHIVA, supra note 47 , at 50.

49. This is the subtitle to Boyle's Shamans, Software, and Spleens, supra note 8 (emphasis added).

50. SHIVA, supra note 47, at 49 (emphasis added). Shiva writes: "Terra nullius has its contemporary equivalent in 'Bio-Nullius'- treating biodiversity knowledge as empty of prior creativity and prior rights, and hence available for 'ownership' through the claim to 'invention." Id.

51. Id.

52. Id. at 64 . 
III

\section{CUlTivators OF KNOWLEDGE}

Today the poor seek to learn how to use the tools of intellectual property to recognize their own cultural and scientific contributions, not just those of the West. Witness the invention of traditional knowledge: In Mysore, India, the makers of internationally famous silk sarees begin offering waterproof sarees. Inlaid marble designers in Agra, home of the Taj Mahal, who for years peddled "hackneyed tourist designs" to visitors now apply their craft to create "stunning dinnerware" to be served in the finest Indian and Western homes. ${ }^{53}$ Traditional people move, intermarry, share ideas, and modify their skills and products to the shifting demands of the market and their culture. These activities are not merely strategic and pragmatic, but are evidence of a healthy and dynamic culture. In short, traditional knowledge is more vibrant and innovative than the "environmentalism" metaphor, with its emphasis on conservation of nature's raw materials, acknowledges.

Debates over the protection of traditional knowledge, however, often fail to recognize its dynamic character. "Traditional knowledge" typically refers to knowledge handed down from generation to generation. This knowledge includes such forms of cultural expressions as songs, dance, stories, artworks, and crafts, as well as "symbols, marks, and other recurring expressions of traditional concepts. ${ }^{, 54}$ Agricultural, scientific, and medical knowledge is also covered.$^{55}$ It is often believed that this knowledge has existed for millennia and, remarkably, that it has remained static over time. We are told that proper authorship cannot be determined because the knowledge has passed through oral tradition and was not written down. Even if inscribed, we may not locate a single author; traditional knowledge is often communally held. Now mix in the historic conception of indigenous and third-world peoples as the anti-West: anti-commodification, anti-property, and anti-markets. The result is that, partly because of the difficulties of fitting poor people's knowledge into western frameworks and partly because this knowledge is valued as the opposite of property, the wealth of creative knowledge and capacity for knowledge-creation of the poor is often overlooked. Instead, poor people's concerns are addressed by stimulating technology transfer, foreign direct investment, access to Western knowledge, and, at best, equitable benefit-sharing. Much less attention is given to how law can tap the innovation and productive knowledge capacities of the poor.

This is beginning to change. A recent World Intellectual Property Organization (WIPO) report on traditional knowledge finds that, in fact, "much

53. Maureen Leibl \& Tirthankar Roy, Handmade in India: Traditional Craft Skills in a Changing World, in Poor PeOple's KnOWledge: Promoting InTellectual Property in DeVeloping COUNTRIES, supra note 11, at 53,69.

54. J. Michael Finger, Introduction and Overview, in PoOR PeOPlE's KNOwledge: Promoting INTELLECTUAL PROPERTY IN DEVELOPING COUNTRIES, supra note 11, at 1, 30.

55. Id. 
[traditional knowledge] is not ancient or inert, but is a vital, dynamic part of the contemporary lives of many communities today." ${ }^{, 5}$ This should not be surprising. Many of the most ancient monuments survived because they remained in use. Traditional knowledge techniques survive in this way, as well, not as static but as continuously evolving as humans innovate around them to meet current needs and solve contemporary problems. Nothing comes naturally. Knowledge requires constant human ingenuity to sustain it. Traditional knowledge, WIPO tells us, "is being created every day and evolves as individuals and communities respond to the challenges posed by their social environment.... This contemporary aspect is further justification for legal protection. ${ }^{, 57}$

Return to the example of Mysore silk sarees. The "grand old queen" of Indian silk ${ }^{58}$ has had a makeover since obtaining a geographical indication, updating its look with trendy new (but interestingly, natural) colors- "lilac, ecru, coffee-brown and elephant-grey"-and "contemporary" designs inspired by temple architecture and tribal jewelry. ${ }^{59}$ Make no mistake: tradition is hard work. As an executive producer of Mysore silk sarees explained, revamping the designs without losing the sheen of the silk took "months of painstaking research and trials. ${ }^{\circ 00}$

Consider another example, closer to home. A San Francisco-based artist trained in the modernist textile tradition of Ray Eames receives a felt rug from her Iranian-American husband, which he purchased in 1999 on his first trip back to Iran after the Revolution. The felt rug, the product of a 7000-year-old tradition, inspired the designer to apply her contemporary paintings to the rugs themselves-a collaboration across cultures and generations. This was an idea that the Internet and the Creative Commons could not assist. Indeed, the couple embarked on a four-year journey across Iran to learn more about felt rug making, to find that only a few living felters remain, sprawled all over that country and unconnected to one another. The couple put the felters in touch and established an Iranian factory employing the best of their techniques, literally reviving an art on the verge of extinction and creating a profitable market for the rugs, both within and beyond Iran. ${ }^{61}$

Tradition is cultivated, not discovered. The concept of traditional knowledge, too, is a modern invention. Those studying poor people's knowledge warn of the dangers of "overdrawing the distinction between

56. World Intellectual Property Organization, InTELlectual ProPerty AND TRAditional KNOWLEDGE 6, available at http://www.wipo.org/freepublications/en/tk/920/wipo_pub_920.pdf (last visited Feb. 24, 2006).

57. Id. (emphasis added).

58. Aruna Chandaraju, Modern MYSURU, THE HINDU, Mar. 3, 2005, available at http://www.hinduonnet.com/thehindu/mp/2005/03/05/stories/2005030502400300.htm.

59. Id.

60. Id.

61. For a more detailed account of the couple's efforts see Peace Industry, http://www.peaceindustry.com/about.html (last visited Mar. 5, 2007). 
[traditional knowledge] and modern knowledge." ${ }^{\circ 2}$ In truth, "no one's life is entirely traditional, and no one's life is entirely modern." ${ }^{63}$ Indeed, forcing ourselves to see the modern aspects of traditional knowledge also helps us to view more critically our own romantic notions of western intellectual property as "new." As Boyle demonstrated so well, the line separating the public domain and intellectual property does not often involve the eureka discovery that the trope of the romantic author suggests.

Developing marketable uses for third-world cultural products is "ultimately perhaps the most effective way to protect their traditions. ${ }^{{ }^{6} 4}$ Increasingly, thirdworld artisans recognize that "[e]xcept in a museum setting, no traditional craft skill can be sustained unless it has a viable market." ${ }^{65}$ And recent activity suggests that many third-world craftspeople and artisans are more marketaccepting than is generally acknowledged. We see again that commerce and culture are not necessarily at odds, as demonstrated by the revitalization of felt rug-making by the introduction of global markets: preservation through commercialization. And vehicles like geographical indications help preserve geographical diversity. ${ }^{66}$ Weavers, artisans, farmers, and the makers of handicrafts do not have to leave their skills or homes for city life. If properly tapped, trained, and protected, they can remain at home and participate in global industry simultaneously.

Intellecual property rights in poor people's knowledge are increasingly considered a key to third-world development-not just in the defensive sense of resisting TRIPs, but also in the offensive approach of writing rights into TRIPs. ${ }^{67}$ Partly, the development interest here is economic, although how much monetary value lies here is uncertain. ${ }^{68}$ Handicrafts alone were estimated to

62. Finger, supra note 54, at 31.

63. Id.

64. Liebl \& Roy, supra note 53, at 70.

65. Id. at 67 .

66. Pedro Echeverria, Letter to the Editor, Fin. Times, July 5, 2004, at 10 ("Better protecting geographical indications would allow for the localization of productions in the framework of trade globalization."); see also Rosemary J. Coombe, Legal Claims to Culture in and Against the Market: Neoliberalism and the Global Proliferation of Meaningful Difference, 1 LAW, CUlTURE \& HUMAN. 35, 46 (2005) (warning that geographical indications may be unduly used to limit competition and exacerbate existing inequalities within groups).

67. See, e.g., InT'L Chamber of COMMERCE, Discussion PAPER, Protecting Traditional KNOWLEDGE 2 (Jan. 2006) ("ICC supports initiatives to help holders of indigenous knowledge use the existing intellecual property system, including through education and studies of ways in which traditional knowledge can be protected by existing rights."), available at http://www.iccwbo.org/ uploadedFiles/ICC/policy/intellectual_property/Statements/Protecting_Traditional_Knowledge.pdf;

Liebl \& Roy, supra note 53, at 56 ("The full potential of the role craft traditions can play in the development process, and specifically in the generation of income... has only recently begun to be appreciated.").

68. Graham Dutfield argues that "estimating the full value of [traditional knowledge] in monetary terms is difficult if not impossible" because it "is often an essential component in the development of other products"; many products derived from traditional knowledge never enter modern markets and thus are not included in GNP calculations; the replacement cost of traditional knowledge would be "quite high"; and the spiritual value of some traditional knowledge cannot be quantified. GRAHAM DUTFIELD, DEVELOPING AND IMPLEMENTING NATIONAL SYSTEMS FOR PROTECTING TRADITIONAL 
hold close to $\$ 3$ billion annually in $2000 .{ }^{69}$ The U.N. estimates that developing countries lose about $\$ 5$ billion in royalties annually from the unauthorized use of traditional knowledge. ${ }^{70}$ Poor people's turn to property is surely about economics, but it is about social and cultural values, as well. These claims recognize that the relationship between intellectual property and development goes beyond GDP. People, rich and poor alike, want recognition of their creativity and their contributions to science and culture. This capacity for innovation, work, and cultural sharing is part of what makes us human.

WIPO and TRIPs have focused on teaching the poor how to protect the intellectual property of the West. We need to turn our attention to helping the poor to use intellectual property to protect their own inventions, as well. Only some of the people who hold traditional knowledge oppose the commodification of their knowledge on religious or cultural grounds; but most are poor, lacking in the infrastructure for production, and are ignorant of intellecual property laws and commercial knowledge of marketing and branding. Intellectual property ownership does not come naturally.

In many cases ... poor people's knowledge meets the standard of novelty that modern IP law demands. ... The development dimension lies in helping poor people to master the commercial/legal tools needed to collect the value of their novelty. This is about entrepreneurship, about finding clever ways to repackage traditional knowledge into products useful for consumers in mass markets, and about developing the capacity to produce and deliver these products in sufficient quantity and quality as to satisfy such markets.

KNowledge: A ReVIEW of EXPeriences in Selected DeVeloping Countries 7 (2000). Compare Graham Dutfield, Legal and Economic Aspects of Traditional Knowledge, in INTERNATIONAL PUblic GoOds AND TRANSFER OF TECHNOLOGY UNDER A GLOBALIZED INTELLECTUAL PROPERTY REGIME 495, 504-05 (Keith E. Maskus \& Jerome H. Reichman eds., 2005) (suggesting that "the global value added to rice yields by use of [Indian] landraces can be estimated at $\$ 400$ million per year") with Stephen B. Brush, Farmers' Rights and Protection of Traditional Agricultural Knowledge 17 (Int'l Food Policy Research Inst., Working Paper No. 36) (noting there is "no estimate of value or widely accepted method to estimate the value of crop genetic resources developed by farmers").

69. Liebl \& Roy, supra note 53, at 54 ("Crafts show tremendous potential in terms of employment generation and poverty alleviation in India. Handicrafts provide a livelihood, albeit modest, to large numbers of poor people in India, and especially to the rural poor."). A recent United Nations Educational, Scientific, and Cultural Organization (UNESCO) symposium concluded, for example, "the industries of the imagination, content, knowledge, innovation and creation clearly are the industries of the future ... they are also important contributory factors to employment and economic growth." Id. at 53 .

70. Coenraad J. Visser, Making Intellectual Property Laws Work for Traditional Knowledge, in Poor People's Knowledge: Promoting Intellectual Property in DeVeloping Countries, supra note 11, at 213. But the turn to intellectual property for the poor is not simply another instance of a misguided, "if value, then right" mentality. See generally Mark A. Lemley, Ex Ante Versus Ex Post Justifications for Intellectual Property, 71 U. CHI. L. REV. 129, 131 (2004); Rochelle Cooper Dreyfuss, Expressive Genericity: Trademarks as Language in the Pepsi Generation, 65 NOTRE DAME L. REV. 397 , 405 (1990). As I argue in Part IV, infra, dismissing these claims on such grounds obscures the ways in which poor people's intellecual property claims present a broader understanding of the purposes and effects of intellecual property law, beyond traditional renderings of intellectual property as incentives alone.

71. Finger, supra note 54, at 35 (emphasis added). 
Increasingly, indigenous people and those in the third world seek "training on IP tools and how to use them." ${ }^{\prime 2}$ The new Indian Geographical Indication Act offers an example. When the Act became effective in 2003, few were aware of its implications. NGOs thus embarked on extensive campaigns to educate local farmers and artisans about GIs. ${ }^{73}$

TRIPs offers a foundation for international recognition of GIs. It defines GIs as "indications which identify a good as originating in the territory of a Member ... where a given quality, reputation, or other characteristic of the good is essentially attributable to its geographical origin." "Champagne," "Tequila," and "Roquefort" present examples of the types of goods recognized as GIs. Under TRIPs, member states must provide legal means to prevent uses of a designated GI that either mislead the public as to the geographical origin of the good or constitute "unfair competition" under Article 10bis of the Paris Convention. ${ }^{75}$ In addition, TRIPs Article 23 mandates that further protection be extended to GIs for "wines and spirits," ${ }^{, 76}$ which must be protected even in the absence of consumer confusion. ${ }^{77}$

Two-tiered protection-a higher level of protection for wines and spirits and a lower one for everything else-has been a source of continuing conflict between Europe and the developing world. ${ }^{78}$ Partly, this is because of a perceived inequity in the current TRIPs system, and partly it is because GIs are considered to be where much of the wealth of poor people lies: in local production methods and cultural goods, from Darjeeling tea to Mysore silk to

72. Id. at 19 .

73. See Jasper Vikas George, Geographical Indications and India, Apr. 3, 2005, http://india.indymedia.org/en/2005/03/210197.shtml (urging Indians to seek GI protection of traditional knowledge).

74. TRIPs, supra note 5, at art. 22(1).

75. Id. at art. 22(2).

76. Id. at art. 23.

77. Id. at art. 23(1) (prohibiting use of the GI when the product does not originate "in the place indicated by the geographical indication ... even where the true origin of the goods is indicated or the geographical indication is used in translation or accompanied by expressions such as 'kind,' 'type,' 'style,' 'imitation' or the like."). The designation "Napa Valley Champagne," for example, even when truthful as to the indication of the product's origin, would be impermissible under the heightened level of protection mandated by TRIPs for wines and spirits.

78. A handful of India's submissions in the WTO relating to TRIPs since 2000 show this. See, e.g., Council for Trade-Related Aspects of Intellectual Property Rights, Communication from Bulgaria, Cuba, Cyprus, the Czech Republic, the European Communities and Their Member States, Georgia, Hungary, Iceland, India, Kenya, Liechtenstein, Malta, Mauritius, Pakistan, Romania, The Slovak Republic, Slovenia, Sri Lanka, Switzerland, Thailand and Turkey, IP/C/W/353 (June 24, 2002) (focusing on "protecting all geographical indications equally"); Council for Trade-Related Aspects of Intellectual Property Rights, Proposal from Bulgaria, Cuba, the Czech Republic, Egypt, Iceland, India, Jamaica, Kenya, Liechtenstein, Mauritius, Nigeria, Pakistan, Slovenia, Sri Lanka, Switzerland, Turkey and Venezuela, IP/C/W/247/Rev.1 (May 17, 2001) ("The TRIPS Agreement does not provide sufficient protection for geographical indications of products other than wines and spirits."); Council for TradeRelated Aspects of Intellectual Property Rights, Communication from India IP/C/W/196 (July 12, 2000) (proposing that "additional protection for geographical indications must be extended for products other than wines and spirits"). 
basmati rice. ${ }^{79}$ The patent provisions of TRIPs have posed clear challenges for developing countries, which typically lack capital for R\&D-intensive breakthroughs or manufacturing capacity. GIs, in contrast, are hailed as the poor people's intellecual property rights, recognizing the knowledge of weavers, farmers, and craftspeople rather than just the high-technology contributions of multi-national corporations. ${ }^{80}$ The structure of GIs does make them particularly suited to poor people's knowledge. First, GIs recognize collective intellecual property rights; under the Indian GI Act, multiple associations of artisans may be recognized as the authorized producers or users of a GI. ${ }^{81}$ GI applications are also relatively cheap, at least for a group of artisans working together. Under the GI Act, it costs a modest 5000 rupees to apply (little more than $\$ 100){ }^{82}$

Although GIs certainly hold promise for the poor, they have limits. The Indian GI Act protects only those goods or processes whose quality or reputation are shown to be "due exclusively or essentially to the geographical environment, with its inherent natural and human factors." ${ }^{83}$ GI applications require "proof of origin" and a "historical record" goods or process. Registrants obtain the exclusive right to use the $\mathrm{GI}^{85}$, and licensing of GIs is prohibited. ${ }^{86}$

Such requirements and restrictions take a narrow view of traditional knowledge, linking culture to land. The rule against alienability poses special concerns. Even if this approach may enable people to remain within their communities (and preserve the physical environment, as well), what if they

79. GI status for basmati rice is controversial because its production is not limited to any particular geographical region in India. Country-wide recognition may also qualify, however. The European Patent and Trademark Office, for example, recently upheld Greece's GI in feta cheese after a decadelong battle with other European countries. Stéphanie Bodon, The EU Feta Debate Concludes, MANAGING INTELlECTUAL PROPERTY, MIP WEEK, Oct. 31, 2005, available at http://www.managingip.com/?Page=9\&PUBID=198\&ISS=20643\&SID=594780\&SM=\&SearchStr=GI.

80. This section is adopted from a larger, related paper, Madhavi Sunder, $I P^{3}, 59$ STAN. L. REV. 257 (2006).

81. The Indian GI Act defines "geographical indication" in relation to goods as

an indication which identifies such goods as agricultural goods, natural goods or manufactured goods as originating, or manufactured in the territory of a country, or a region or locality in that territory, where a given quality, reputation or other characteristic of such goods is essentially attributable to its geographical origin and in case where such goods are manufactured goods one of the activities of either the production or of processing or preparation of the goods concerned takes place in such territory, region or locality, as the case may be.

Geographical Indication of Goods (Registration and Protection) Act of 1999, No. 48, Acts of Parliament, 1999 § I-1(3)(e).

82. The cost to renew a GI is 3000 rupees. The Geographical Indication of Goods (Registration and Protection) Rules, 2002, The First Schedule, 4A. Once approved, GIs and all producers and authorized users of the GIs are listed in a national register. Geographical Indication of Goods Act §II5-6. Registration lasts for ten years and is renewable "from time to time" for periods of an additional 10 years. Id. § III-18.

83. Id. § III-11(2).

84. Geographical Indication of Goods Rules § Form GI-1.

85. Geographical Indication of Goods Act $\S$ IV-21(1-b).

86. Id. § IV-24. 
move? What rights do traditional weavers from Mysore have if they move to North India-or the U.K. ${ }^{97}$ Of course, there are good reasons to prevent the alienation of the GI from the particular geographical community. It prevents the scenario in which a large foreign corporation hires a member of that community away and then begins to produce "authentic" work elsewhere, using that GI-and decimating the livelihoods of the traditional community left behind. At the same time, such a restriction could stifle opportunities for some individuals, as they remain within a traditional community by economic necessity, not choice. People move, intermarry, and change jobs. Culture flows with them. The GI Act does not recognize this dynamic nature of culture, ossifying authentic production in today's localities.

Within a recognized "association," traditional leaders may impose their will on members, reifying traditional hierarchies. ${ }^{88}$ Elizabeth Povinelli notes that cultural rights often lead to the ironic production of authenticity or indigeneity, which conforms to traditional structures from the past, rather than celebrating cultures as diachronic peoples who are dynamic and heterogeneous. ${ }^{89}$

GIs also pose economic concerns. While GIs protect Darjeeling tea, for example, they also prohibit the Indian manufacture of Scotch whiskey, driving up the cost of Scotch in India. It is possible that the poor may reap greater economic rewards in a system with fewer production constraints. ${ }^{90}$ Boyle's concern about the public domain also applies; at which point does too much intellectual property impede the very processes of cultural sharing and innovation that law ought to promote, especially to aid the little guy in cultural production? These economic concerns raise an important question of liberal

87. See Liebl \& Roy, supra note 53, at 65 (asking "[a]nd what happens when a weaver from another part of India moves to Kanjeevaram," famous for its silk sarees?).

88. See, e.g., Madhavi Sunder, Cultural Dissent, 54 StAN. L. REV. 495, 504 (2001) (urging assurance that "legal efforts to counter globalization and modernization do not buttress the hegemony of cultural elites and suppress efforts by cultural dissenters to gain autonomy and equality within their cultural context"); Madhavi Sunder, Intellectual Property and Identity Politics: Playing with Fire, 4 J. GENDER, RACE \& JUST. 69, 70 (2000) (discussing "the new centrality of struggles over discursive power-the right to create, and control, cultural meanings"); see Coombe, supra note 66.

89. See Elizabeth Povinelli, At Home in the Violence of Recognition, in ProPERTY IN QUESTION: VALUE TRANSFORMATION IN THE Global ECONOMY 185, 185-206 (Katherine Verdery \& Caroline Humphrey eds., 2004) (describing pressure on indigenous peoples to present their communities as "a synchronic structure" that comports to legal requirements for land based on colonial notions of authentic difference). See generally Rosemary J. Coombe et al., Bearing Cultural Distinction: Informational Capitalism and New Expectations for Intellectual Property, in INTELLECTUAL PROPERTY Law: Articles On Crossing Borders Between Traditional And ACtual 193, 193-213 (F. Willem Grosheide \& Jan J. Brinkhof eds., 2005); Cristina Grasseni, Packaging Skills: Calibrating Cheese to the Global Market, in COMMODIFYING EVERYTHING: RELATIONSHIPS OF THE MARKET 259 (Susan Strasser ed., 2003) (describing commodification of tradition in the context of local cheese production in Europe).

90. COMM'N ON INTEllectual Property Rights, InTEgrating INTEllectual Property Rights AND DEVELOPMENT POLICY 90 (2002). Cf. Kal Raustiala \& Chris Sprigman, Eat, Drink and Be Wary: Why the U.S. Should Oppose the WTO's Extending Stringent Intellectual Property Protection of Wine and Spirit Names to Other Products, FInDLAw, Dec. 12, 2002, http://writ.news.findlaw.com/ commentary/20021212_sprigman.html (highlighting free-speech concerns posed by heightened GI protection). 
strategy. As critical legal theorists have aptly warned, we must stand ready to openly question when and how "rights" might work to the disadvantage of the poor rather than to the poor's benefit."

These concerns notwithstanding, GIs do potentially offer a range of benefits, from recognizing the innovation of collectives, to preserving geographic diversity and stimulating some redistribution of wealth. It may be more important to think of GIs as part of a larger framework in which the poor learn the secrets of Madison Avenue. If one simply produces goods, then any successful product will eventually draw stiff competition from global mass production. But creating a protected brand allows one to stave off complete usurpation by mass-produced substitutes. The GI Act works on this principle. It rewards the local community for having created a valued reputation and protects that reputation from the forces of global commerce. It recognizes that consumers everywhere seek authentic products and that they may care about who produces something, not just the ultimate product. ${ }^{92}$ Fair Trade coffee, Rugmark carpets, and dolphin-safe tuna, for example, appeal to people's desire to consume free from the worry about exploitation in the process of production. In response to the commercialization of ghetto style by white-owned fashion houses, one African American company declares to the consumer its ghetto roots by branding itself "FUBU"-For Us, By Us. Such authenticity marks translate into profits in the marketplace.

The goal is "to help poor people get along in the modern world-to use modern instruments for managing the ownership of knowledge either to collect on the commercial value of that knowledge or to prevent its use in a way that its owners consider inappropriate. ${ }^{, 93}$ New organizations such as Light Years IP are emerging to address this need, specializing in marketing and branding a developing country's intellectual property. ${ }^{94}$

The Danish artists' collective Superflex has pioneered this strategy. The Superflex "Supercopy" art collaboration employs what it calls a "countereconomic strategy" to teach local farmers in the third world how to convert their biodiversity and traditional knowledge into branded end-products, which

91. See DunCAn Kennedy, A CRitique of AdjudicAtion 334 (1997) (describing his own "loss of faith" in rights as always producing positive outcomes for the disempowered). Kennedy advocates a critical stance toward the discourse of rights but does not abandon rights altogether. Id. Cf. Daria Roithmayr, Left Over Rights, 22 CARDOZO L. REV. 1113, 1113-34 (2001) (arguing for pragmatic use of rights arguments by communities of color).

92. See Douglas A. Kysar, Preferences for Processes: The Process/Product Distinction and the Regulation of Consumer Choice, 118 HARV. L. REV. 525, 529 (2004) (noting that "consumer preferences may be heavily influenced by information regarding the manner in which goods are produced").

93. Finger, supra note 54 , at 3.

94. See generally Light Years IP, http://www.lightyearsip.net (last visited Mar. 5, 2007) (recognizing that "within the last two decades, intellectual property has rapidly become the central means to create wealth in almost all industries," and that "[t]here is an urgent need to increase knowledge and capability in developing country producers, exporters and government managers in the tasks of assessing intangible value opportunities, identifying IP solutions and implementing them."). 
will eventually compete with the products of global multinationals. In one ongoing collaboration, Superflex works with a farmers' cooperative in Maues, Brazil. This region in the Amazon is famous for cultivating the guarana berry, prized by the local population for its perceived medicinal and energy-giving properties. The Dutch multinational Ambev and Pepsi Co. have successfully marketed global energy drinks derived from this plant, most notably Ambev's "Antarctica" drink. The local Maues farmers complained that the multinationals have formed a cartel, driving down the price of the guarana berries from $\$ 25 /$ kilo to $\$ 4 /$ kilo. So the cooperative is fighting back. In collaboration with Superflex, farmers held brainstorming sessions to begin developing their own product and designing a label for it. One member, for example, suggested a coffee drink called Maues Café, evoking the internationally popular Nescafé drink, as depicted in Figure 1.

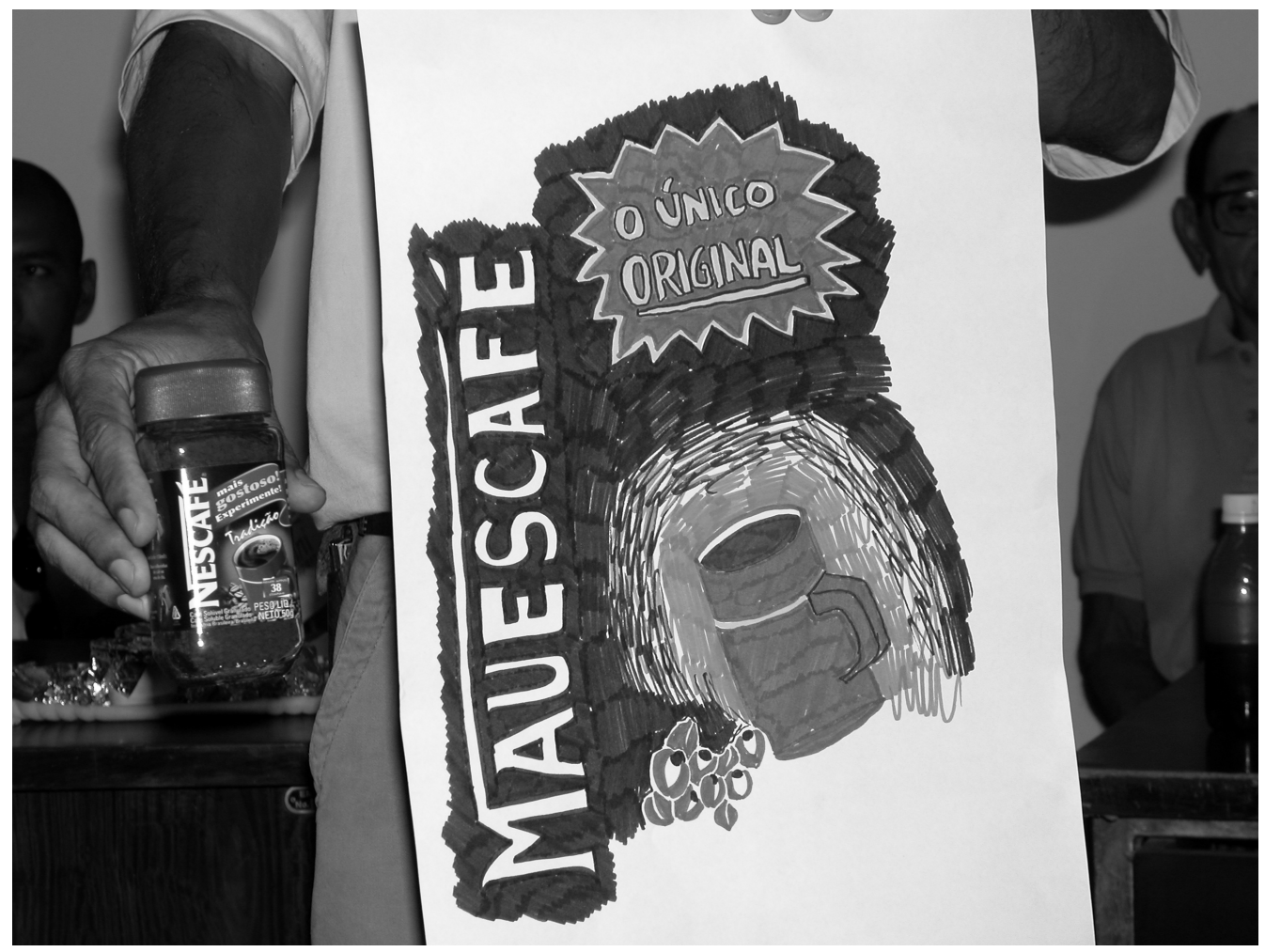

Figure 1. Maues Café

Eventually, the cooperative decided to manufacture and distribute a soft drink: Guarana Power. Members designed a label for the drink, which comprises a photograph of local farmers affixed atop the familiar Antarctica 
label. Guarana Power's marketing slogan? “[O]riginal Maues guarana for energy and empowerment." See Figure 2.

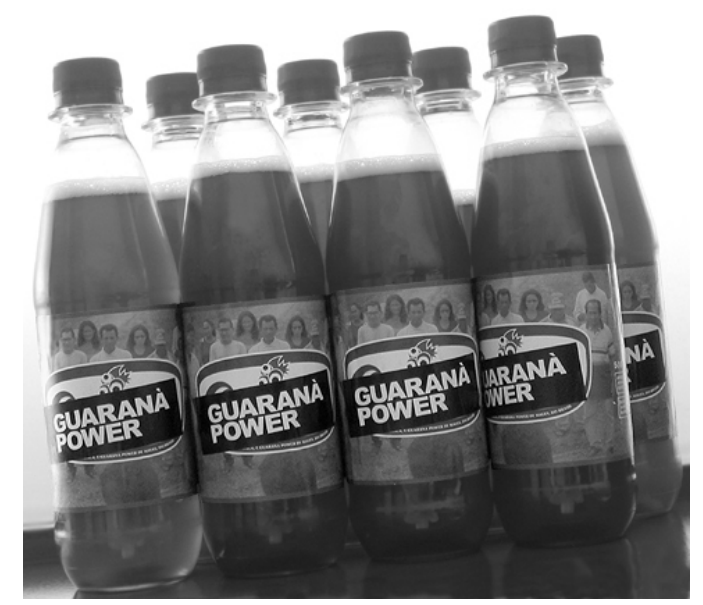

Photo by Jeppe Gudmundsen-Holmgreen

Figure 2. Guarana Power, with logo pasted over multinational brand label

The Superflex collaboration turns on a simple idea: empowerment for the poor will entail the poor learning to control and market their own knowledge products. In the words of Superflex (appropriated from Ani DiFranco): "Every tool is a weapon if you hold it right.." ${ }^{\prime 5}$ The Maues collective spoke with lawyers about intellecual property rights, raised capital, paired with a production company in Denmark, and searched for global distributors for Guarana Power. ${ }^{96}$ Superflex's Guarana Power gallery floor reproduces the shop floor, taking visitors on a journey from producing to bottling, labeling, refrigerating, and tasting Guarana Power.

95. Jennifer Allen, Superflex: Rooseum-Reviews: Amsterdam - Bjornstjerne Reuter Christiansen, Jakob Fenger, and Rasmus Nielsen, ARTFORUM, Feb. 2003, http://www.findarticles.com/p/articles/ mi_m0268/is_6_41/ai_98123170 (last visited Feb. 24, 2006).

96. Anupam Chander, Illegal Art? The Artists' Group Superflex Co-Opts Global Trademarks, FINDLAW, May 13, 2004, http://writ.news.findlaw.com/commentary/20040513_chander.html; Anupam Chander, Guaraná Power to the People, SUPERfLEX.NeT, May 2004, http://www.superflex.net/ guaranapower/main.php?page=strategy\&id=2. 
IV

\section{LAW AND THE CONSTRUCTION OF THE KNOWLEDGE SOCIETY}

"Without ignoring the importance of economic growth, we must look well beyond it."

-Amartya Sen, Development as Freedom ${ }^{97}$

In October 2004, the WIPO General Assembly declared that intellecual property law needs to incorporate a "development agenda." ${ }^{\text {" }}$ WIPO responded in part to the Geneva Declaration, a call from hundreds of scientists, scholars, and activists to reorient intellecual property law in favor of the "[1]ongneglected concerns of the poor, the sick, the visually impaired and others." ${ }^{99}$ Consider too this handful of major intellecual property conferences in the first four months of 2006: Access to Knowledge at Yale Law School; a Michigan State conference on human rights issues in international intellectual property; this very conference on cultural environmentalism hosted by Stanford; and a conference on "Intellectual Property and Social Justice" at my own law school at the University of California, Davis. All these gatherings sound the same theme: that intellecual property law must confront its vast social effects and serve a broader range of human values.

But when Boyle wrote Shamans, Software and Spleens, law-and-economic analysis was hegemonic in the legal academy. Accordingly, Boyle defended cultural environmentalism on a utilitarian metric. Today, it is increasingly evident that utilitarianism fails as a comprehensive theory of intellectual property, either descriptively or prescriptively. ${ }^{100}$ Neither economic nor legal scholars can make economic sense of the most important intellecual property cases of our generation, from Eldred v. Ashcroft ${ }^{101}$ to Grokster v. MGM. ${ }^{102}$ Meanwhile, technological advances, including the World Wide Web itself, ${ }^{103}$ undermine utilitarian intellecual property law's very premise: that intellecual

97. Amartya Sen, DeVelopment As Freedom 14 (1999).

98. General Assembly Decision on a Development Agenda, Oct. 4, 2004, available at http://www.cptech.org/ip/wipo/wipo10042004.html.

99. Geneva Declaration on the Future of the World Intellectual Property Organization, Oct. 2004, available at http://www.cptech.org/ip/wipo/futureofwipodeclaration.pdf.

100. See Sunder, supra note 80.

101. 537 U.S. 186 (2003); see id. at 254 (saying of the Copyright Term Extension Act of 1998, "no one could reasonably conclude that copyright's traditional economic rationale applies here") (Breyer, J., dissenting); id. at 257 ("in respect to works already created ... the statute creates no economic incentive at all") (Breyer, J., dissenting); id. at 263 ("There is no legitimate, serious copyright-related justification for this statute.") (Breyer, J., dissenting); see also Eldred v. Ashcroft, Amicus Brief of George A. Akerlof, Kenneth J. Arrow, et al., filed May 20, 2002, at 2 (statement of leading economists, including five Nobel Laureates, arguing that "[t]he term extension for existing works makes no significant contribution to an author's economic incentive to create").

102. 545 U.S. 125 (2005); see also Sunder, supra note 80 (arguing that Grokster turned on the common-law principles of fairness and morality, not economic efficiency).

103. See generally TIM BERNERS-LEE, WEAVING THE WEB (1999) (recounting Berners-Lee's successful effort to convince his employer, CERN, to forgo intellecual property rights in his invention). 
property rights are necessary to incentivize creation. ${ }^{104}$ The expansion of intellecual property law to the developing world through TRIPS and bilateral agreements has paradoxically weakened, rather than strengthened, the utilitarian understanding of intellectual property: we now know that many poor nations lack the infrastructure and resources required to create and commercialize their own knowledge. ${ }^{105}$

So we must now think beyond incentives, but to what? The preamble to TRIPs stipulates that intellecual property rights must promote "development," but it leaves that concept undefined. For the United States, establishing intellecual property law is itself development-such law will attract foreign direct investment and spur indigenous creation.

But many see this understanding of development as much too narrow. ${ }^{106}$ Demands to expand the ambit of values served by intellectual property abound. Artists and students around the world are joining in a "Free Culture" movement. Indigenous peoples complain of the ransacking of their cultural knowledge and environment. HIV-AIDS activists work to secure access to lifesaving medicines for the world's poor. Farmers demand the right to replant seeds. Cultural environmentalists seek to preserve biodiversity and cultural communities. There is growing consensus that intellecual property law ought to have a "development agenda," but not much agreement yet about what such a broad agenda for intellectual property and development would require.

We have already been here: Recall the brilliant move made by Mahbub Ul Haq fifteen years ago when he fashioned the Human Development Report for the United Nations. That report countered the earlier dominance of GDP-

104. The question is by no means new. See, e.g., Stephen Breyer, The Uneasy Case for Copyright: A Study of Copyright in Books, Photocopies, and Computer Programs, HARV. L. REV. 281, 281-82 (1970) (suggesting that a working wage, possibly supplemented by government subsidies for expressive works, may be sufficient incentive for sufficient expressive works).

105. See COMM'N ON INTElleCtuAl PROPERTY Rights, supra note 90, at 22 (2002) ("[I]n most low income countries, with a weak scientific and technological infrastructure, IP protection at the levels mandated by TRIPS is not a significant determinant of growth. On the contrary, rapid growth is more often associated with weaker IP protection."); Peter Drahos, Introduction, in GlOBAL INTELLECTUAL PROPERTY Rights: KNOWLedge, ACCESS AND DeVElopment 1, 1 (Peter Drahos \& Ruth Mayne eds., 2002) ("[G]lobal intellectual property rules may well be an obstacle to development."); Martin Khor, Rethinking Intellectual Property Rights and TRIPS, in GlOBAL INTELleCtUAL PrOPERTY Rights: KNOWledge, ACCESS AND DeVelopment 201, 205 (Peter Drahos \& Ruth Mayne eds., 2002) ("The one-size-fits-all, or rather one-standard-fits-all, approach of TRIPS is a great disservice to developing countries.").

106. See, e.g., Elaboration of Issues, supra note 26, II 21 (clarifying "that the development dimension of intellectual property is NOT the same thing as technical assistance."). An Indian representative to WIPO put it this way:

'Development' in WIPO's terminology means increasing a developing country's capacity to provide protection to the owners of intellectual property rights. This is quite the opposite of what developing countries understand when they refer to the 'development dimension'.... The real 'development' imperative is ensuring that the interest of Intellectual Property owners is not secured at the expense of the users of IP, of consumers at large, and of public policy in general.

Inter-Sessional Intergovernmental Meeting on a Development Agenda for WIPO, Statement by India, IIM/1 (Apr. 11-13, 2005) 
based evaluations of social welfare. It built a positive measure of development from a number of disgruntled constituencies. Amartya Sen describes Mahbub Ul Haq's strategy as shaping the negative energy of these multiple constituencies into a single, positive vision:

\begin{abstract}
Mahbub [Ul Haq] took on the leadership of large armies of discontent that were gunning, somewhat sporadically, at the single-minded concentration on the GNP. There were activists arguing for the recognition of 'basic needs'. There were international interventionists lamenting 'the state of the world's children'. There were relief organizations concerned with hunger and epidemics. There were writers focusing on 'disparities' between the actual lives of the rich and the poor. There were humanists voicing the need for social justice in the quality of life. There were advocates of measures of physical quality of life. There were even some philosophically oriented critics wondering about the bigger insights into social ethics provided in the far-reaching works of Aristotle, Adam Smith, Karl Marx, and even of John Stuart Mill. It is to the credit of Mahbub's integrating vision that he saw the possibility of harnessing these different discontents into the development of a capacious alternative outlook which would be, at once, both practical and broad, and which could accommodate-however roughly—these different concerns. ${ }^{107}$
\end{abstract}

Since 1990, the United Nations has understood development in the broad terms of expanding human capabilities, thanks in no small part to Sen himself. Ul Haq's Human Development Report and Sen's vision of "development as freedom" are pluralist, measuring development based on the capacity for many freedoms, including, but not limited to, market-oriented freedoms. These freedoms range from basic needs, such as the right to life and health, to more expansive freedoms of movement, creative work, and participation in social, economic, and cultural institutions. ${ }^{108}$ Furthermore, Sen's theory recognizes the interrelatedness of rights: the right to labor and remuneration for one's creations, including intellectual creations, affects the right to health, and vice versa. ${ }^{109}$

Intellectual property law is essential to development, not just in the narrow sense of efficiency but in this broader view of expanding capability for central freedoms. Surely, copyrights and patents determine our access to basic needs, from educational materials to life-saving medicines. What is less obvious is that failure to be recognized as an author or inventor may impede one's access to these essential life goods by diminishing one's material wealth and the capability for living a full life. Stated differently, the implications in intellectual property rights go well beyond incentives for innovation; these rights are related to questions of cultural relations, social development, and GDP growth. As a new study by the National Commission on Women in India shows, intellecual property laws even implicate physical security. The Report argues that TRIPs, which recharacterized women's farming knowledge as "raw

107. Amartya Sen, A Decade of Human Development, 1 J. Human DEV. 17, 21 (2000).

108. See generally SEN, supra note 97.

109. Id. 
materials" for corporations to appropriate, has reduced women's profits and led to a corresponding rise in violence against women. ${ }^{110}$

The traditional utilitarian understanding of intellectual property focuses on incentivizing the creation of more knowledge goods. Boyle's shaman would preserve a rich public domain in order to promote this goal. But utilitarianism does not ask who makes the goods or whether the goods are fairly distributed to all who need them. A broader understanding of intellectual property recognizes the importance not just of producing more knowledge goods, but also of participating in the process of knowledge creation. Recognizing people's humanity requires acknowledging their production of knowledge of the world. The United Nations' conception of a "Knowledge Society" articulates this in terms of the products and processes of knowledge creation. In the Knowledge Age, social, cultural, and economic freedom will require not only access to knowledge products, but also access to the processes of creating knowledge. As a U.N. report puts it, "the Knowledge Society is not only about technological innovations, but also about human beings, their personal growth and their individual creativity, experience and participation ... at its best, the Knowledge Society involves all members of a community in knowledge creation and utilization." 111 The principal assets of a Knowledge Society are "information ... that triggers people's creative reflection" and "people ... as creative beings and carriers of tacit knowledge." 112

Recognizing access to knowledge as consisting in both products and processes is essential as we craft a "development agenda" for intellectual property. ${ }^{113}$ We may ask first, How might intellecual property law enhance access to knowledge products - such as, for example, by not making textbooks and pharmaceuticals cost prohibitive to people who live on two dollars a day? One such mechanism is the "developing nations license," a Creative Commons license that allows copyright holders to distribute their work freely in the third world, but demand market prices in the developed world. Similarly, the draft Treaty on Access to Knowledge would permit countries where urgently needed medicines are unaffordable at market prices to temporarily distribute these medicines at cost for "compassionate use." 114 Both the developing nations

110. INDIAN NAT'L COMM'N FOR WOMEN, IMPACT OF WTO ON WOMEN IN AGRICULTURE: A REPORT BY RESEARCH FOUNDATION FOR SCIENCE, TECHNOLOGY \& ECOLOGY (2005).

111. U.N. Div. for Pub. Admin. \& Dev. Mgmt., Dep't of Econ. \& Social Affairs, Report: Understanding Knowledge Societies, xi, U.N. Doc. ST/ESA/PAD/SER.E/66 (2005). UNESCO, for example, emphasizes the importance of both "access to information" and "capacity building." UNESCO's focus on the latter consists of "providing people with the skills and abilities for critical reception, assessment and use of information in their professional and personal lives." UNESCO Home Page, http://portal.unesco.org/ci/en/ev.php-URL_ID=19487\&URL_DO=DO_TOPIC\&URL_ SECTION=201.html (last visited Feb. 20, 2006).

112. U.N. Div. for Pub. Admin. \& Dev. Mgmt., Dep't of Econ. \& Social Affairs, supra note 111, at xi.

113. This discussion is adopted from Sunder, supra note 80 .

114. TREATY ON ACCESS TO KNOWLEDGE, supra note 35, at art. 4(1)(b)(iv). 
license and the draft Treaty provision act as mechanisms for wealth distribution from the richer to the poorer parts of the world.

At the same time, we must consider how intellecual property law and policy may enhance the capacity for participating in the processes of knowledge creation. The Indian GI Act, for example, recognizes the poor as producers of knowledge and promotes their participation in global markets. Rather than focus just on the reception of knowledge goods, the GI Act-and a vast campaign by NGO's to teach poor people about it-focuses on teaching people how to recognize and market their own knowledge production. The GI Act takes an "agent-oriented" view of development, recognizing that "[w]ith adequate social opportunities, individuals can effectively shape their own destiny and help each other." 115 These individuals "need not be seen primarily as passive recipients of the benefits of cunning development programs." 116

Focusing on development as freedom and agency also gives us a metric upon which to assess the Indian GI Act. For one thing, a geographical indication works by denying many the ability to identify a good by a particular name. But in so doing, it recognizes the quality and reputation cultivated by particular communities, and, like traditional trademarks, prohibits others from free-riding off that reputation. It thereby empowers local communities, which can continue to commercialize their products without fearing displacement by global mass production. Of course, GIs might circumscribe freedom if those within the community are forced to play defined roles in the production process or are prevented from leaving. As Sen writes, an economy premised upon agency and freedom will value "free labor contract and unrestrained physical movement" in contrast to the "bonded labor and forced work" characteristic of traditional economies. ${ }^{117}$ A core value in Sen's development-as-freedom approach is that "the people must be allowed to decide freely what traditions they wish or not wish to follow." 118

To be sure, this broadened understanding of intellectual property may require the recognition of new intellecual property rights, awarding private control over resources once thought to be in the public domain. ${ }^{119}$ For this reason alone, some may be tempted to reject new rationales for intellectual property. That this vision does not fit comfortably into the Originalist view of intellectual property, however, does not mean we should dismiss it. Ten years ago, Boyle boldly stated that our intellecual property system was not working.

115. SEN, supra note 97 , at 11.

116. Id.

117. Id. at 28 .

118. Id.

119. Of course, understanding the importance of access to knowledge, in the form of both products and processes, will also provide new rationales for limiting intellecual property rights. For example, compulsory licenses for third-world development of life-saving drugs enhance the public domain, at least when the public domain is understood as "[r]esources for which legal rights to access and use for free (or for nominal sums) are held broadly." Chander \& Sunder, supra note 39, at 1338. 
Now, we must confront the fact that the utilitarian theory of intellectual property, without more, is not working.

\section{$\mathrm{V}$ \\ CONCLUSION}

The poor must be recognized as both receivers and producers of knowledge. Failing to promote poor people's capacity for creative work and their participation in global culture and commercial markets hinders development as freedom. As Sen writes, "the rejection of the freedom to participate in the labor market is one of the ways of keeping people in bondage and captivity." ${ }^{120}$ In the Knowledge Age, wealth lies not simply in access to other people's knowledge (although this is certainly important), but also in the ability to produce new knowledge and to benefit from this creation, culturally and economically. 